\title{
International Helgoland Symposium: Convener's report on the Informal Session on biomass and productivity of microorganisms in planktonic ecosystems
}

\author{
J. MCN. SIEBURTH \\ Graduate School of Oceanography, \\ University of Rhode Island; Kingston, Rhode Island, USA
}

\begin{abstract}
This paper is a brief report on an informal session held during the International Helgoland Symposium 1976. On the basis of a tape recording and notes, it has been prepared by the author who acted as convener of the session. The report indicates that many in the community of marine biologists are not quite ready to accept the increasing evidence of a substantial biomass of bacterioplankton and its apparent activity. Equally skeptical are a few marine bacteriologists who cannot accept the primary productivity and heterotrophic potential estimates obtained with ${ }^{14} \mathrm{C}$ bottle experiments which fail to show oceanic values commensurate with bacterioplankton values obtained with other means. The discussants apparently agree to disagree until the reasons for the apparent discrepancy are known.
\end{abstract}

\section{INTRODUCTION}

Marine biologists studying microbial plankton in the sea today are faced with the realization that the oversimplification of former years must be modified in line with current information. The food chains and webs of the open sea are more complex than the paradigm of copepods feeding on diatom blooms. A few investigators (including Erickson, Sieburth and colleagues - this symposium) have indications that a sizable biomass of protozoans effectively compete with the phytoplankton-grazing copepods. During this feeding process, significant quantities of dissolved organic matter are apparently released to nurture a sizable population of bacterioplankton. These 0.2 to $1.0 \mu \mathrm{m}$ wide cells which are free living and not attached to particles apparently accomplish a rapid in-situ recycling of a major protion of the released DOC (dissolved organic carbon) within hours, and contribute a substantial biomass to the plankton. Observations on the release and uptake of this dissolved organic matter and on the biomass and estimated rates of growth of the bacterioplankton indicate a much higher production of organic matter at specific depths and horizontal patches than is indicated by current methods for the estimation of biomass from chlorophyll and primary production from ${ }^{14} \mathrm{C}$ uptake. 
Sorokin (1971a, b, 1975) has shown a sizable production of bacterioplankton whose biomass can approach that of the phytoplankton. On the basis of independent oceanographic evidence, Banse (1974) suggested that the accepted values of primary production are probably within a factor of two of actual production indicating that Sorokin's estimates must be an order of magnitude too high. Sieburth et al. (1977) used independent methods to estimate the rates of release and uptake of dissolved organic matter as well as the biomass and growth patterns of bacterioplankton in the open North Atlantic Ocean. Preliminary data indicate that bacterioplankton, according to observations of Sorokin, constitutes a significant proportion of the total microbial plankton. Our values for biomass and productivity for the Atlantic are somewhat higher than those obtained by Sorokin for the Pacific Ocean.

In arranging for this session with O. Kinne, K. Banse and Y. Sorokin were invited as principal discussants. Unfortunately Vinogradov informed me that Sorokin's relocation to the Institute of Oceanology's branch at Galendzik will prevent his attendance. Before starting the discussion I would like to point out that the bacteriologists are not the only ones questioning the accepted values for primary production. Steele (1974) and Mills (1975), who are concerned with the nekton, conclude that accepted levels of primary productivity cannot account for actual production. The persistence of estuarine levels of labile carbohydrates, a drop of only a half order magnitude in dissolved organic carbon and a drop of only an order of magnitude in bacterioplankton biomass as one goes from estuary to the open sea contradicts the classic picture shown by Ryther (1969) which may be a gross underestimation of actual production. Either the accepted methods for estimating phytoplankton biomass and productivity give serious underestimations for the open sea, or we bacteriologists are off by an order of magnitude or more. Banse pointed out during this session that phytoplankton assimilation numbers for the sea are well established and recorded in reviews and physiological textbooks. The only way that oceanic productivity could be grossly underestimated is if the chlorophyll observations are untrustworthy.

Banse (1974) has pointed out that Sorokin's data (Sorokin, 1971) on bacterial production in the photic zone exceeds the published rates of phytoplankton production by several times. Since Sorokin uses the classical method for phytoplankton production and gets low numbers and cannot explain the source of DOC for heterotrophic bacterial growth solely on the observed $25 \%$ phytoplankton excretion rate, he explains this bacterial growth on the basis of upwelling of DOC from the deep sea. But such an upwelling does not occur. Therefore Banse contends that Sorokin's ideas are untenable and that bacterial production must be a fraction of phytoplankton production. He further points out that Sorokin's numbers for bacterial production in the deep sea are an order of magnitude too high for the reported values of oxygen consumption in the deep sea.

Following the presentation of both sides of the argument by Sieburth and Banse there was a lively exchange of questions and five-minute presentations on data and viewpoints. In order to present the main points in a logical order these have been divided into three major topics: (1) the validity of methods used to estimate phytoplankton biomass and primary activity; (2) the validity of the estimates of bacterial 
biomass and production; (3) from where could this large fraction of the microplankton be gathering their nutrients?

\section{VALIDITY OF PHYTOPLANKTON DATA}

Banse took the stance that despite the criticisms that primary production is being underestimated, he can see perhaps a two-fold, but not a ten-fold difference from accepted values. His first assumption was that biomass estimates, especially the chlorophyll determinations, are essentially correct although conceding that the conversion to algal carbon is a very difficult matter. Sieburth pointed out that biomass values for nearshore waters where diatoms dominate are probably close but in offshore waters where very fragile nanoplankton dominates, the biomass estimations are probably very low. Bernhard discussed his work in the Gulf of Genoa, which showed that the standing crop of nanoplankton, which is easily destroyed by fixatives, was ten times greater than the plankton counted by the Utermöhl method. By using these populations and multiplying by arbitrary multiplication rates, an estimate of the share of productivity of the nanoplankton independent of ${ }^{14} \mathrm{C}$-procedures was obtained. The contribution of the nanoplankton population was estimated to equal that of the Utermöhl plankton. In the open sea this may be more significant. Jooris and Wangersky pointed out the necessity of being specific about where the observations were from, due to great variation in space, time and diurnal activity.

Banse pointed out that despite the numerous errors in the ${ }^{14} \mathrm{C}$-method, there are two ways of using physiological data to estimate if the ${ }^{14} \mathrm{C}$-method is grossly underestimating productivity. (1) One way is to use the doubling rates from Eppley's (1972) review article which presents optimal growth rates of algal cultures, and to compare these with productivity rates at similar temperatures. (2) The other is to use the plant physiological literature on the rates of carbon assimilation per unit of chlorophyll ("assimilation numbers") versus temperature (cf. the issue of carbon/chlorophyll ratios in. Eppley, 1972). This is a very simple- minded way to see if ${ }^{14} \mathrm{C}$-uptake values are reasonable or not.

Banse pointed out that maximal growth rates in the oceans do approach the laboratory assimilation numbers but that in the subtropical gyres, doubling rates were about $1 / 10$ the maximal values. From the chemostat literature one could extrapolate that the growth rate under the nutrient concentrations observed may be just about $1 / 10$ of the maximum. The assimilation numbers in the gyres suggest essentially the same. Banse concluded that photosynthetic rates as determined with the ${ }^{14} \mathrm{C}$-method cannot be too far off.

Sieburth objected to the extrapolation of the results of chemostat experiments to conditions in the open sea. Chemostat experiments can demonstrate relationships and phenomena but to assume that the kinetics are the same is foolhardy. Holger Jannasch using a chemostat demonstrated that there is a threshold value for dissolved organic substrates below which bacteria will not utilize them further (Jannasch, 1970). But the levels he found were many milligrams per liter. The pre-dawn mininal concentrations for total monosaccharides we found during "Trident" Cruise 170 across the open At- 
lantic were some 70 to $80 \mu \mathrm{g}$ of carbohydrate carbon per liter. Sieburth said that if one extrapolated Jannasch's values from the chemostat in the lab (which he never intended) one would get a very false impression of what actually occurs in the sea. To understand microbial life in the sea you must study it in the sea. That is what current marine microbiology is all about.

Sieburth went on to point out that there is a great danger in extrapolating from one set of conditions to another. There is a role for each type of observation. There is a role for chemostats and there is a role for experimental ecosystems. But to extrapolate from these results to an estuary or the open sea is meaningless. For the past several days we have been hearing about ecosystem and microcosm work. These systems are interesting to study but they end up looking more like eutrophic tide pools than the estuary they are supposed to mimic. Sieburth also questioned the results of assay techniques for primary productivity and heterotrophic potential done in a bottle under "standardized" conditions. Since most workers use the same procedures and get comparable results they get encouraged to believe these values. This may be a very false feeling of security. The apparent flux of dissolved organic matter reported this morning is not observed in single substrate uptake bottle experiments. Sieburth asked that we show a healthy skepticism of these standardized productivity measurements so that we are not prevented from finding out what is actually happening in the sea. Current studies on heterotrophy indicate that autotrophic processes must be more productive than estimated. Just because the methods to date have not shown a sufficient phytoplankton biomass and productivity in the open sea to account for it doesn't mean that it can not or does not exist. Bacteriologists looked at holes in bacterial colonies for years but it wasn't until Stolp \& Starr (1963) took a careful look, did they find $B$ dellovibrio, a very ubiquitous and numerous bacteria-eating bacterium shown to exist in most soils and waters.

\section{VALIDITY OF BACTERIOPLANKTON DATA}

Van Ess stated that there is much evidence that primary production could be in the range that is measured and asked what evidence do we bacteriologists have for saying that bacterioplankton constitutes a sizable fraction of the plankton and is produced at a considerable rate. In a similar vein, Landry wanted to know precisely the order of magnitude of bacterioplankton biomass per square meter of surface. Bernhard (Naples) cited the work of his colleagues Peroni \& Lavarello (1975) who used ${ }^{32} \mathrm{P}$-autoradiography to show minimal activity of small populations $\left(10^{3} / \mathrm{ml}\right.$ in the upper two-hundred meters) which were even sparser with depth, which he said confirms the work of Jannasch and colleagues in the deep sea (Jannasch et al., 1971; Jannasch \& Wirsen, 1973).

Gunderson reported on his experience in the central North Pacific while he was in Hawaii. From his experiences with culturing bacteria, direct microscopy and the dark fixation of ${ }^{14} \mathrm{C}$, he feels that the number of bacteria free in the plankton are not so significant, accounting for only $10 \%$ of $\mathrm{O}_{2}$ uptake. But he went on to state that on a 24-h-basis, heterotrophic bacteria account for some $50 \%$ of oxygen production in the 
photic zone. From recent studies in Sweden he ascribed this activity to bacteria localized on detritus such as fecal pellets, which can be cultured in good numbers. Sieburth agreed that certain high nutrient sites such as fecal material (Sieburth, 1976) and the surface skin of the sea (Sieburth et al., 1976) can yield high numbers of cultivable bacteria. But he also pointed out that below the surface skin which is enriched to the levels of laboratory media, there is also a sizable population of bacterioplankton which has been shown by a variety of methods which is on the borderline of starvation living on transient accumulations of dissolved organic matter released by protozoa and copepods through excretion and perhaps from phytoplankton exudation and autolysis. Such bacteria can be grown on in-situ dissolved organic matter but not on laboratory media.

Iturriaga spoke of preliminary work with Hoppe at Kiel in which they studied the heterotrophic uptake of bacteria from phytoplankton exudates. They observed heterotrophic uptake ranged between 8 and $70 \%$ of primary productivity and concluded that the Steeman-Nielsen ${ }^{14} \mathrm{C}$-technique was probably underestimating productivity.

Meyer-Reil also from Kiel reported on bacterioplankton biomass production for the Kiel Bight, using a flow-through (diffusion culture) apparatus to approximate natural conditions. Bacterial cell production equalled 15 to $40 \%$ of the primary production. His yearly production value for this eutrophic nearshore location was 1-6 g of bacterial carbon $\mathrm{m}^{-3}$ year ${ }^{-1}$. Meyer-Reil commented that this was the same range that Sorokin obtained for the tropical Pacific Ocean and that the data of Sieburth et al. for the North Atlantic also fell in this range.

Sieburth commented on the ATP data obtained by Lavoie during "Trident" Cruise 170 and presented by Sieburth et al. (1977). By selective filtration of the less than $3 \mu \mathrm{m}$ and greater than $3 \mu \mathrm{m}$ fraction below $1000 \mu \mathrm{m}$ and assuming the former to be mainly bacterioplankton, then this smaller fraction accounts for 3 to $80 \%$ of the total particulate ATP which averaged out to $30 \%$ from the photic zone and $40 \%$ from the aphotic zone. It is interesting that Sorokin with the Romanenko method of dark ${ }^{14} \mathrm{C}$-uptake, Hoppe and Iturriaga with autoradiography and other methods and Meyer-Reil with epifluorescence and diffusion culture, and Sieburth's lab with selective filtration and ATP data, get similar results showing that a significant fraction of the plankton in a variety of environments occurs as bacterioplankton.

\section{SOURCE OF NUTRIENTS FOR THE BACTERIOPLANKTON?}

Mommaerts discussed his comparison of primary productivity and bacterial productivity in the same Belgian slough as reported by Joiris (1977). He agreed with Banse that bacterial production is a small fraction of primary production on a diurnal, but not a seasonal, basis. In regard to the way nutrients are derived from phytoplankton for bacterioplankton, Mommaerts commented that the values for phytoplankton excretion are decreasing through the years. The first values at the time of Fogg $\&$ Watt (Fogg et al., 1965) were up to $50 \%$ of production while the most recent values from Williams and Yentsch (1976) were from 0 to $6 \%$. He wondered if excretion per se 
exists at all. He stated that on the other hand he has indirect evidence of light lysis by phytoplankton. This heavy mortality was seen in biomass and net production values and was beyond that accounted for by sedimentation, advection and grazing. Mommaerts believes that we might have to modify our concept of excretion to one of natural mortality as a result of light-caused lysis.

Tranter from Cronulla presented data obtained by Smith \& Wiebe (1976) on the release of dissolved organic matter from phytoplankton. There has been the assumption that DOC release is directly related to and is expressed in regard to the production of photosynthesate or POC. These workers observed that in well buffered systems, although the production of POC fell away with limiting concentrations of $\mathrm{CO}_{2}$ the release of DOC remained essentially constant at all $\mathrm{CO}_{2}$ concentrations. They concluded that either the two systems are uncoupled in photosynthesis or there is some separate control over the production of DOC. Tranter commented that if this occurs in nature and phytoplankton are leaking out photosynthesate quite independently of particulate production and if this production of DOC is available for microbial uptake, then quite a considerable amount of primary production could get quickly recycled as the convenor has said. The turnover time for the organic carbon pool in the fairly unpolluted estuarine system of Port Hacking is $8 / 4 \mathrm{~h}$. Tranter wondered whether a substantial part of what we call primary production is in fact microbial production based on photosynthesate being very quickly leaked out from the phytoplankton. Sieburth commented on the association of a pigment deficient biomass indicative of protozoan accumulations at the depths of transient DOC accumulations, and pointed out that a biomass of phytoplankton roughly equal to the doubling rate would be consumed daily and that an appreciable fraction of it would be released as DOC. Banse wondered whether there was evidence in the literature on productivity $\left({ }^{14} \mathrm{C}\right)$ experiments which would show a rapid loss of newly (last few hours) assimilated material. For instance, samples filtered after $12 \mathrm{~h}$ of photosynthetic ${ }^{14} \mathrm{C}$-uptake should be very different from others kept for 12 subsequent hours in the dark. Sieburth pointed out that it is not that simple since there is a diurnal cycling of release and uptake of DOC with different patterns occurring at different depths depending on whether the protist fraction was rich or poor in plant pigment. However on a 24-hour basis, the 3 generations of bacterioplankton growth would approximate the one third of a day turnover time reported by Tranter.

\section{CONCLUSIONS}

There is a growing body of data showing that a significant fraction of the microplankton, perhaps as much as $30 \%$ in the photic zone, consists of bacterioplankton which occurs as cells under a micron in width which defy culture on laboratory media. The skeptics cannot see how accepted levels of primary production can account for such bacterial productivity. It is difficult to see how so many different methods would all be making the same mistake - while all primary productivity measurements use the same standard method and have numerous shortcomings in determining both biomass and rates of increase. 
It is only natural that a "new idea" will meet resistance. Many are skeptical about a process that hints at gross inefficiency. The amount of primary productivity that must go rather quickly to DOC to support this bacterioplankton is an example. When Khailov \& Burlakova (1969) and Sieburth (1969) reported that up to $40 \%$ of the photosynthesis of the large browns is released during the early spring, this was challenged by Mann (1974) and Moebus \& Johnson (1974) among others. However, current work at Dalhousie by Mann and a Ph. D. student and by Johnston et al. (1977) using independent methods show that for Laminaria a release of 30 to $40 \%$ of production occurs when photosynthesis occurs but growth has not yet begun, so that the plants dump the excess.

Until we know more about the basic biology of in-situ microplankton including the interrelationships of the microalgae, protozoa and bacteria through diel periodicity and through their microzonal depths of activity, then it is premature to discount the presence of an extensive bacterioplankton utilizing DOC in-situ in the photic zone just on the basis of chemostat studies, chlorophyll biomass estimates, and ${ }^{14} \mathrm{C}$-bottle uptake experiments with their well-recognized limitations.

Acknowledgement. The assistance of Dr. K. Banse (Seattle, Washington, U.S.A.) in preparing this report is sincerely appreciated.

\section{LITERATURE CITED}

Banse, K., 1974. On the role of bacterioplankton in the tropical ocean. Mar. Biol, 24, 1-5.

Eppley, R. W., 1972. Temperature and phytoplankton growth in the sea. Fish. Bull. U.S. 70, 1063-1085.

Fogg, G. E., Nalewajko, C. \& Watt, W. D., 1965. Extracellular products of phytoplankton photosynthesis. Proc. R. Soc. (B) 162, 517-532.

Jannasch, H. W., 1970. Threshold concentrations of carbon sources limiting bacterial growth in sea water. In: Organic matter in natural waters. Ed. by D. W. Hood. Inst. Mar. Sci., Univ. of Alaska, College, Alaska, 321-328. (Occ. Publ. 1)

- \& Wirsen, C. O., 1973. Deep-sea microorganisms: in situ response to nutrient enrichment. Science, N. Y. 180, 641-643.

- Eimhjellen, K., Wirsen, C. O. \& Farmanfarmaian, A., 1971. Microbial degradation of organic matter in the deep sea. Science, N. Y. 171, 672-675.

Johnston, C. S., Jones R. G. \& Hunt, R. D., 1977. A seasonal carbon budget for a laminarian population in a Scottish Sea-Loch. Helgoländer wiss. Meeresunters. 30, 527-545.

Joiris, C., 1977. On the role of heterotrophic bacteria in marine ecosystems: Some problems. Helgoländer wiss. Meeresunters. 30, 611-621.

Khailov, K. M. \& Burlakova, Z. P., 1969. Release of dissolved organic matter by marine seaweeds and distribution of their total organic production to inshore communities. Limnol. Oceanogr. 14, 521-527.

Mann, K. H., 1974. Seaweeds: their productivity and strategy for growth. Science, N. Y. 182, 975-981.

Mills, E. L., 1975. Benthic organisms and the structure of marine ecosystems. J. Fish. Res. Bd Can. 32, 1657-1663.

Moebus, K. \& Johnson, K. M., 1974. Exudation of dissolved organic carbon by brown algae. Mar. Biol. 26, 117-125.

Peroni, C. \& Lavarello, O., 1975. Microbial activities as a function of water depth in the Ligurian sea: an autoradiographic study. Mar. Biol. 30, 37-50.

Ryther, J. H., 1969. Photosynthesis and fish production in the sea. Science, N. Y. 166, 72-76. 
Sieburth, J. McN., 1969. Studies on algal substances in the sea. III. The production of extracellular organic matter by littoral marine algae. J. exp. mar. Biol. Ecol. 3, 290-309.

- 1975. Microbial seascapes. Univ. Park Press, Baltimore, Md., 248 pp.

- 1976. Bacterial substrates and productivity in marine ecosystems. A. Rev. Ecol. Syst. 7, 259-285.

- Johnson, K. M., Burney, C. M. \& Lavoie, D. M., 1977. Estimation of in-situ rates of heterotrophy using diurnal changes in dissolved organic matter and growth rates of picoplankton in diffusion culture. Helgoländer wiss. Meeresunters. 30, 565-574.

- Willis, P.-J., Johnson, K. M., Burney, C. M., Lavoie, D. M., Hinga, K. R., Caron, D. A., French, F. W., Johnson, P. W. \& Davis, P. G., 1976. Dissolved organic matter and heterotrophic microneuston in the surface microlayers of the North Atlantic. Science, N. Y. 194, 1415-1418.

Smith, D. F. \& Wiebe, W. J., 1976. Constant release of photosynthate from marine phytoplankton. Appl, environm. Microbiol. 32, 75-79.

Sorokin, Yu. I., 1971a. On the role of bacteria in the productivity of tropical oceanic waters. Int. Revue ges. Hydrobiol. 56, 1-48.

- 1971b. Bacterial populations as components of oceanic ecosystems. Mar. Biol. 11, 101-105.

- 1975. Vertical structure and production of a microplankton community in the sea of Japan in summer. Okeanologiya 14, 327-333.

Steele, J. H., 1974. The structure of marine ecosystems. Harvard Univ. Press, Cambridge, Ma. $128 \mathrm{pp}$.

Stolp, H. \& Starr, M. P., 1963. Bdellovibrio bacteriovorus gen. et sp. n., a predatory, ectoparasitic, and bacteriolytic microorganism. Antonie van Leeuwenhoek 29, 217-248.

Williams, P. J. Le B. \& Yentsch, C. S., 1976. An examination of photosynthetic production, excretion of photosynthetic products, and heterotrophic utilization of dissolved organic compounds with reference to results from a coastal subtropical sea. Mar. Biol. 35, 31-40.

\author{
Author's address: J. McN. Sieburth \\ Graduate School of Oceanography \\ University of Rhode Island \\ Kingston, Rhode Island 02881 \\ USA
}

